\title{
Decentralization and Economic Performance in Indonesia
}

\author{
Thomas B. Pepinsky and Maria M. Wihardja
}

\begin{abstract}
Indonesia's 1999 decentralization law gave local governments in Indonesia an unprecedented opportunity to adopt prodevelopment policies. In this article, we study whether decentralization has in fact generated improved economic performance in Indonesia. Using a synthetic case control methodology, we argue that Indonesian decentralization has had no discernable effect on the country's national-level economic performance. To explain why not, we use subnational data to probe two political economy mechanisms-interjurisdictional competition and democratic accountability-that underlie all theories linking decentralization to better economic outcomes. Our findings suggest that extreme heterogeneity in endowments, factor immobility, and the endogenous deterioration of local governance institutions can each undermine the supposed development-enhancing promises of decentralized government in emerging economies such as Indonesia. KEYWORDS: Indonesia, decentralization, economic development, case control methods
\end{abstract}

SINCE 2001, INDONESIA HAS EMBARKED ON A PROGRAM OF POLITICAL AND economic decentralization that has fundamentally altered the political economy of the world's fourth most populous country. The law implementing decentralization (Indonesia 1999) focused on improving the ability of local governments to respond to local conditions, but research commonly links decentralization with superior national economic performance (see Breuss and Eller 2004 for a review). Most simply, if decentralization yields development-enhancing policies at the local level, then the sum of the effects of these policies should be improved economic performance for the country as a whole. Other theoretical links between decentralization and national economic performance include more participatory policymaking (Cheema and Rondinelli 1983), lower inflation (Qian and Roland 1998), decreased corruption (Gurgur and Shah 2005), and more responsive taxation and public spending (Tiebout 1956; Oates 1993). Accordingly, decentralization is a national develop- 
ment policy that can yield national development outcomes-in the words of one Indonesian observer, "through decentralization various national problems will be solved at the regional level by using local means to cope with local challenges" (Simandjuntak 2003, 1).

The specific mechanisms through which decentralization may affect economic development depend on how decentralization is implemented: under political decentralization, local governments gain autonomous control over some local policies; under fiscal decentralization, local governments gain the ability to levy their own taxes; under various forms of federalism, local governments may have veto authority over national policies. ${ }^{1}$ Indonesia's 1999 decentralization law was more political than fiscal or federal, and local revenues still come primarily through grants from the central government known as DAU (dana alokasi umum, general allocation grants). Local taxation capabilities, though, were expanded in 2000, and local districts do have autonomous control over their own budgets. ${ }^{2}$ This combination of political and fiscal decentralization has afforded local governments unprecedented responsibility for "all areas of government except for foreign policy, safety, law, monetary and fiscal policy, religion, and other matters" (Indonesia 1999; see also Brodjonegoro 2009; Seymour and Turner 2002). Indonesia's decentralization has been heralded as a landmark policy for advancing Indonesian development by giving local governments the ability to adopt locally appropriate regulations, to spend DAU funds in ways seen as suitable for local needs, and to experiment with development- and welfare-enhancing policies.

Indonesia's 2001 switch to decentralized governance was rapidHofman and Kaiser (2003) call it a "Big Bang"-and fundamentally transformed Indonesia's political economy. However, evidence that decentralization has improved Indonesia's national economic performance is elusive. National growth rates since decentralization, for instance, still lag behind those achieved under the highly centralized New Order regime (1966-1998) prior to the Asian financial crisis (see Figure 1). Furthermore, there are countless examples of provincial and local governments that appear unwilling to take advantage of the opportunities that decentralization has afforded them to create competitive business environments and responsive social service administrations. Even if decentralization policy has empowered some local governments to adopt good policies, it may also have empowered others to adopt bad policies. The net effect of decentralization on Indonesia's economic performance therefore remains unclear.

Beyond Indonesia's relatively disappointing economic performance in the decade following decentralization, there are theoretical reasons to 
Figure 1 Indonesia, Yearly Per Capita Real GDP Growth, 1991-2007

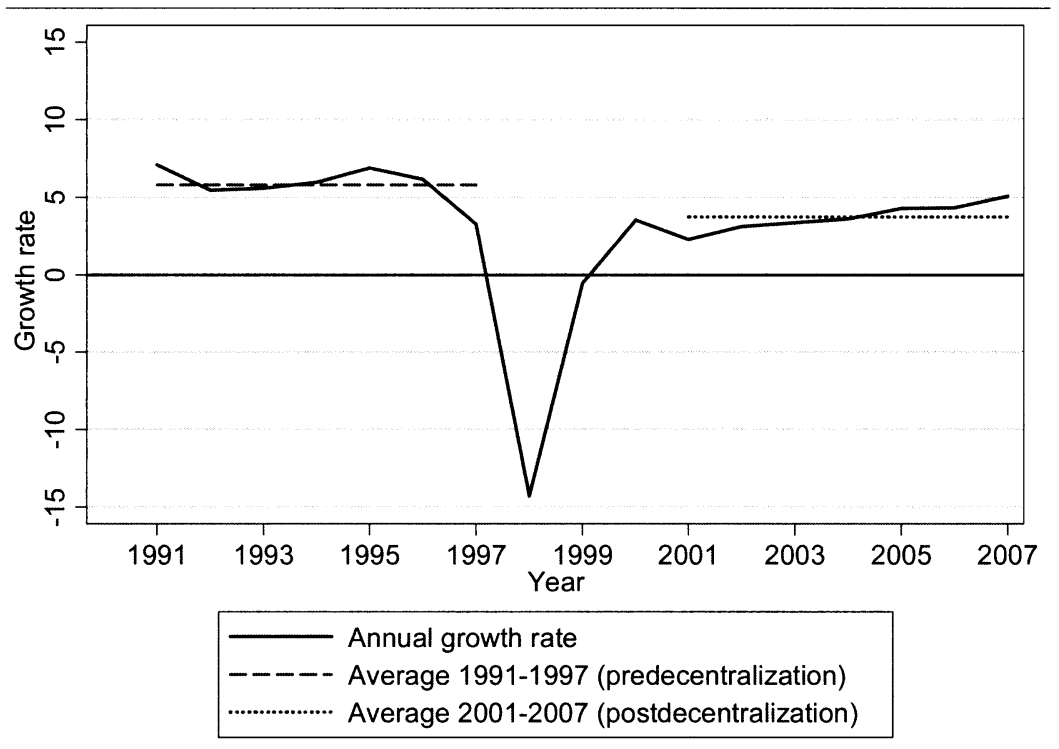

be skeptical about whether decentralization improves economic performance. Jorge Martinez-Vazquez and Robert McNab (2003) review a number of theoretical and empirical links between (fiscal) decentralization and economic growth and argue that there is insufficient evidence to conclude that decentralization will necessarily promote improved economic performance. Empirically, it is difficult to disentangle the direction of causality from institutional innovations such as decentralization to outcomes such as economic growth. Theoretically, the links between decentralization and economic growth are largely indirect and depend on a series of intermediate claims that must be demonstrated rather than assumed. For example, if decentralization improves economic performance by increasing allocative efficiency, then two nonobvious claims must be true: first, that decentralization actually increases allocative efficiency, and, second, that allocative efficiency promotes economic growth.

Attuned to the challenges identified by Martinez-Vazquez and $\mathrm{McNab}$ and others, our article makes two contributions. First, we concentrate on a single important case-Indonesia - and show that decentralization has not been associated with a rise in Indonesia's economic output over and above the economic trajectory that we would have expected had Indonesia not decentralized. The empirical challenge in making this 
claim is that decentralization occurred amid a number of other important changes in Indonesia's economy, including democratization and the painful aftermath of a severe financial crisis. To separate the effect of decentralization from these and other factors, we adopt a synthetic case control research strategy proposed by Alberto Abadie, Alexis Diamond, and Jens Hainmueller (2010). We use information from other developing and emerging economies to construct a "synthetic" Indonesia that is as close as possible to Indonesia but that did not decentralize. Using this strategy, we estimate that Indonesia's economic output (as measured by gross domestic product [GDP]) remains nearly identical to what we predict from a synthetic Indonesia that has not decentralized, and that this gap has not decreased since the onset of decentralization in 2001.

Second, to explain why decentralization has not improved Indonesia's economic trajectory in the way that many of decentralization's proponents believe that it should, we explore three pathologies of Indonesian decentralization that undermine decentralization's desired outcomes: heterogeneity in endowments across jurisdictions, factor immobility, and endogenous institutional quality. We support our arguments using a mix of individual-level survey data, subnational economic data, and comparative case studies. We argue that heterogeneity in endowments across Indonesian districts suggests that the mere imposition of decentralized governance will not force local governments to compete for resources. Moreover, even it were reasonable to expect that decentralization could prompt competition, the immobility of both labor and capital across jurisdictional boundaries has prevented factors of production from "voting with their feet," suggesting that local politicians may be able to exploit productive assets rather than competing for them. And finally, we argue, using qualitative research in carefully selected field sites, that local political institutions in backward areas have themselves deteriorated in response to decentralization. This endogenous institutional decay has undermined the foundations upon which successful local development might occur in the districts where it is most necessary.

These findings contribute to recent studies that explore the logic of decentralization in an attempt to understand the conditions under which its salutary benefits are likely to be achieved (see Treisman 2007). Before proceeding, though, we wish to make two things clear. First, ours is not a critique of decentralization as a theoretical concept or as a strategy practiced in any other country. We have no doubt that under certain conditions (although perhaps very restrictive ones) we should expect that decentralization will increase national welfare. Moreover, economic output is not the only metric to measure the "success" of Indonesia's decen- 
tralization. Other metrics by which to judge decentralization's success may include other national economic outcomes such as inflation or central government deficits, or local outcomes such as civil violence, political participation, or public goods provision. For example, by giving citizens greater ability to participate in government, decentralized government may be normatively superior to centralized government even if it does not contribute to national development. We leave the systematic study of these alternative measures of decentralization's impact on Indonesia for future research.

Second, we make no claim that we have exhaustively catalogued all of the challenges facing Indonesia in the era of decentralization. MartinezVazquez and McNab (2003) identify a number of potential links between decentralization and economic performance that space constraints prevent us from considering. Likewise, we do not attempt to gauge the relative importance of each of the three pathologies we identify for explaining why decentralization has not been associated with better economic outcomes in Indonesia. Our goals are more modest: to estimate the overall effect of decentralization on Indonesian national development and to probe several plausible reasons why we find that this effect is zero.

The article consists of three parts. In the next section, we present our main empirical results, illustrating our case control approach to the study of decentralization's effects on Indonesia's economic performance. To explain these findings, we then probe several of the theoretical mechanisms linking decentralization to national economic development, identifying three key political economy factors that are critical for decentralization to be successful and providing descriptive evidence that illustrates how each has hindered national economic development since 2001. In our final section we conclude our argument and discuss its implications for decentralization and development in Indonesia and beyond.

\section{Estimating Decentralization's Effect on Indonesian Economic Performance}

The key inferential problem in studying how this transformation has shaped Indonesia's development trajectory is constructing a valid counterfactual. The Neyman-Rubin causal model (Holland 1986) helps to clarify our objectives. We define the effect of decentralization on Indonesian development as the difference in economic development between an Indonesia that has decentralized and an Indonesia that has not decentralized. Decentralization here can be considered much like a medical treatment, the effect of which is studied by examining the average difference in 
health outcomes between those patients who have taken the treatment and those who have not. The problem is that observing this quantity - the difference in economic development between an Indonesia that has decentralized and an Indonesia that has not decentralized-is impossible. Instead, we observe only economic development in Indonesia prior to decentralization and economic development in Indonesia after decentralization. The proper comparison would be between an Indonesia with decentralization and an Indonesia without decentralization. We cannot, of course, observe the latter.

One way to proceed would be to collect data from all countries in the world and compare those countries that have decentralized with those that have not. Doing so, however, recasts the research question as one of estimating the average effect of decentralization across all countries and therefore is not suited to addressing the effect of decentralization on Indonesian national development. Moreover, Indonesia's unique decentralization process has no obvious parallel among other countries, so it is not clear what other countries display the relevant characteristics that would lead us to differentiate them from other countries that lack them. To take one example, Indonesian decentralization gave policy autonomy not to the first tier of subnational government (provinces) but rather to the second tier, that of districts or regencies (kabupaten) and cities (kota). (For clarity, in this article we refer to all second-tier governments as "regencies.") We do not believe it is possible to assume that Indonesia's postdecentralization governance structure is equivalent to that of, say, India or the Philippines across all relevant dimensions.

Alternatively, we might select a single country that shared many of Indonesia's characteristics prior to decentralization but did not decentralize and chart how development has subsequently proceeded in the two countries. If variables held to have determined economic development prior to decentralization were similar in both countries, then we may infer that difference in development between the "treated" Indonesia and the "control" country after Indonesian decentralization is attributable to decentralization itself. Yet no single country seems an obvious parallel to Indonesia at the close of the twentieth century-a middle-income country with a large population, an outward-directed development model, relatively high adult literacy rates, a long period of authoritarian rule followed by abrupt democratization, and a long period of rapid growth followed by a severe economic meltdown. Some countries (Bangladesh, Brazil, China, India, Malaysia, Mexico, Pakistan, the Philippines, South Africa, Thailand) share one or two of these characteristics, but none shares all of them. 
This observation - that while no country shares all of Indonesia's characteristics, many countries share some of Indonesia's characteristicsforms the basis of our empirical strategy. Abadie, Diamond, and Hainmueller (2010) formalize this as a synthetic case control methodology to gauge the effect of an intervention (in our case, decentralization) on a treated unit (in our case, Indonesia) and the uncertainty around that estimate. Let $Y_{1}$ stand for the post-treatment outcome in the treated case, let $X_{1}$ stand for the possible determinants of that outcome in the treated case, let $Y_{0}$ stand for the outcome in all nontreated cases, and let $X_{0}$ stand for the determinants of $Y_{0}$ in the nontreated cases. The core insight of Abadie, Diamond, and Hainmueller is that a weighted average of the sample of available control units (in our case, all countries aside from Indonesia) can form a "synthetic" Indonesia that is far more similar across all possible determinants of the outcome of interest than is any single control unit. The weights $W^{*}$ are chosen by searching across the entire set of possible weights to minimize the difference between the synthetic control and the treated unit prior to the intervention; that is, to minimize $X_{1}-X_{0} W$ according to some distance metric. ${ }^{3}$ In our application, this means choosing $W^{*}$ to produce a synthetic Indonesia whose determinants of economic development were as similar as possible to Indonesia's prior to decentralization in 2001. The growth trajectory of this synthetic Indonesia after 2001, or $Y_{1}^{*}=Y_{0} W$, simulates the counterfactual of Indonesia's growth trajectory absent decentralization. To see how Indonesia's growth trajectory differs from that of the synthetic control case, we simply compare $Y_{1 \mathrm{t}}{ }^{*}$ and $Y_{1 \mathrm{t}}$, where $t$ indexes each year after decentralization.

This method has several attractive features. Most importantly, it exploits the full range of information available from all possible control cases and does not require that any single control case be considered the perfect counterfactual. This method also "makes explicit: (1) the relative contribution of each control unit to the counterfactual of interest; and (2) the similarities (or lack thereof) between the unit affected by the event or intervention of interest and the synthetic control, in terms of preintervention outcomes and other predictors of postintervention outcomes" (Abadie, Diamond, and Hainmueller 2010, 494).

Finally, it is possible to provide some sense of the uncertainty surrounding the estimated effects of the treatment through a "placebo" methodology, estimating the "effect" of the treatment for all remaining cases in the sample-none of which actually experienced it. If, on average, the estimated effect for the treated case is large relative to the estimated effect from a placebo case chosen at random, this increases our confidence that the treatment truly had an effect. We generate synthetic control cases 
for every country in our sample, as if each decentralized in 2001 . We then compare these with the effects we estimate for Indonesia to determine whether the estimate for Indonesia differs systematically from these.

We measure economic development using the natural log of GDP per capita in constant 2000 US dollars ( $L N G D P P C)$. A list of common predictors of GDP per capita, which comprise the variables we will use to construct a synthetic case control version of Indonesia, appears in Table 1.

Our choice of variables is somewhat more expansive than that of the existing literature using synthetic case control methods to study economic development (e.g., Abadie and Gardeazabal 2003), because we want to account for both the important political changes that have affected Indonesia since 1998 and the painful economic reversal that accompanied the Asian financial crisis. To accomplish the former, we add data on political democracy, regime durability, checks and balances, and federalism. To accomplish the latter, we use lagged versions of $L N G D P P C$ in 1990 (the first year in our sample), in 1996 (the year before the onset of the Asian financial crisis), and in 2000 (the year before the onset of decentralization in 2001) as additional predictors, along with a variable denoting the existence of a speculative attack on a country's currency. Excluding both the lags of $L N G D P P C$ and the additional political variables in our analysis in no way changes our substantive inferences about the consequences of Indonesian decentralization, although the root mean squared prediction error (RMSPE) of the outcome variable increases when we omit prior values of $L N G D P P C$ as predictors.

We choose a wide sample of countries as possible control countries, selecting all countries for which data are available for at least some portion of the period prior to 2001 and whose per capita GDP is less than US $\$ 10,000$ in constant 2000 prices. Our broadest sample includes sixtynine possible control countries (see Appendix), although this sum shrinks to sixty-five possible control countries when we adopt an expanded set of predictors that includes political variables and adult literacy. Below, we show results using both the restricted set of predictors (Model 1) and the expanded set of predictors (Model 2). We also show results using only Asian countries as possible predictors (Model 3). Finally we eliminate the six countries with decentralized political structures that appear in our dataset (Argentina, Brazil, India, Mexico, Malaysia, and Venezuela) (Model 4).

Data on pretreatment predictors for Indonesia and synthetic control countries, across all models, appear in Table 2 . We also include the average for all available control cases as a reference, as well as the relative 
Table 1 Predictors of the Per Capita Gross Domestic Product (logged)

\begin{tabular}{|c|c|c|}
\hline Variable & Definition & Source \\
\hline $\begin{array}{l}\text { CONSUMPTION SHARE } \\
\text { OF GDP }\end{array}$ & $\begin{array}{l}\text { Consumption share } \\
\text { of GDP }\end{array}$ & Heston et al. (2006) \\
\hline $\begin{array}{l}\text { GOVERNMENT SHARE } \\
\quad \text { OF GDP }\end{array}$ & $\begin{array}{l}\text { Government share } \\
\text { of GDP }\end{array}$ & Heston et al. (2006) \\
\hline $\begin{array}{l}\text { INVESTMENT SHARE } \\
\quad \text { OF GDP }\end{array}$ & $\begin{array}{l}\text { Investment share of } \\
\text { of GDP }\end{array}$ & Heston et al. (2006) \\
\hline $\begin{array}{l}\text { EXPORTS AND IMPORTS/ } \\
\quad G D P\end{array}$ & $\begin{array}{l}\text { Exports plus imports } \\
\text { as a share of GDP }\end{array}$ & Heston et al. (2006) \\
\hline ANNUAL INFLATION RATE & $\begin{array}{l}\text { Annual percentage } \\
\text { change in implicit } \\
\text { GDP deflator }\end{array}$ & World Bank (2009) \\
\hline $\begin{array}{l}\text { SPECULATIVE ATTACK, } \\
\text { 1997-1998 }\end{array}$ & $\begin{array}{l}1 \text { if speculative attack, } \\
0 \text { otherwise, average } \\
\text { for } 1997 \text { and } 1998\end{array}$ & Leblang (2005) \\
\hline LNGDPPC, 1990 & $\begin{array}{l}\text { Natural log of per capita } \\
\text { real GDP, } 1990\end{array}$ & World Bank (2009) \\
\hline LNGDPPC, 1996 & $\begin{array}{l}\text { Natural log of per capita } \\
\quad \text { real GDP, } 1996\end{array}$ & World Bank (2009) \\
\hline$L N G D P P C, 2000$ & $\begin{array}{l}\text { Natural log of per capita } \\
\text { real GDP, } 2000\end{array}$ & World Bank (2009) \\
\hline LN (POPULATION) & Natural log of population & World Bank (2009) \\
\hline URBANIZATION & Percent urban population & World Bank (2009) \\
\hline ETHNIC HETEROGENEITY & $\begin{array}{l}\text { Probability that two } \\
\text { citizens are from } \\
\text { different ethnic groups, } \\
1985\end{array}$ & $\begin{array}{l}\text { Roeder (2001); } \\
\quad \text { Teorell et al. (2009) }\end{array}$ \\
\hline CORRUPTION, 1998 & $\begin{array}{l}\text { Average of corruption } \\
\text { scores, } 1998\end{array}$ & $\begin{array}{l}\text { Kaufmann et al. (2008); } \\
\text { Teorell et al. (2009) }\end{array}$ \\
\hline $\begin{array}{l}\text { ADULT LITERACY RATE, } \\
\quad 1993\end{array}$ & $\begin{array}{l}\text { Adult literacy rate, } 1993 \\
\text { or closest available year }\end{array}$ & World Bank (2009) \\
\hline Political Regime & $\begin{array}{l}\text { Polity IV democracy } \\
\text { score-autocracy score }\end{array}$ & Marshall et al. (2010) \\
\hline REGIME DURABILITY & $\begin{array}{l}\text { Number of years since } \\
\text { last change in political } \\
\text { regime }\end{array}$ & Marshall et al. (2010) \\
\hline CHECKS & Number of veto players & $\begin{array}{l}\text { Beck et al. (2001); } \\
\text { Teorell et al. (2009) }\end{array}$ \\
\hline FEDERALISM & $\begin{array}{l}1 \text { if federal political } \\
\text { structure, } 0 \text { otherwise, } \\
1998^{\mathrm{a}}\end{array}$ & $\begin{array}{l}\text { Persson and Tabellini } \\
\text { (2003); Teorell et al. } \\
\text { (2009) }\end{array}$ \\
\hline
\end{tabular}

Note: a. Original source only coded democratic countries; here, nondemocratic countries are coded as nonfederal. 
contributions of each country to the synthetic control and the error of the estimate.

As Table 2 shows, across most variables in all four models, a weighted average of control countries is an improvement over a simple average of all control countries for Indonesia. The notable exception is for the political variables POLITICAL REGIME and DURABILITY, where our synthetic controls are less similar to Indonesia than a simple average of all countries. We have experimented with a number of measures of political regimes and with other time periods, and all produce synthetic controls whose balance is even worse. We interpret this to mean that we simply do not have sufficient data among our control units to produce a suitable counterpart for Indonesia on these political variables. Finally, in all four models, the RMSPE of the outcome variable is small; the placebo studies presented here give a sense of how small this is.

Our main results appear in Figure 2. Each graph shows the path of LNGDPPC for Indonesia (solid line) and the synthetic control case (dashed line) from 1990 until 2007. We are unfortunately constrained by crossnational data availability to end our analysis in 2007 . The vertical lines at 2001 mark the onset of decentralization. There are two important conclusions from this figure. First, in all four models, Indonesia's level of development prior to 1997 tracks very closely that of its synthetic counterpart. This correspondence breaks down during the Asian financial crisis, which simply indicates that the crisis in Indonesia was worse than might have been expected given standard determinants of economic output, ${ }^{4}$ but prior to 1997 our method performs very well in creating a synthetic control for Indonesia. The second and more striking conclusion is that the lines corresponding to Indonesia and its synthetic counterpart track one another extremely well after 2001 in all four models as well. That is, the development trajectory for Indonesia since the onset of decentralization is nearly identical to what we might expect for a country that had similar economic, demographic, and political fundamentals but did not decentralize. This holds regardless of the variables that we use to predict economic development, and regardless of which countries we consider as appropriate control countries. We estimate the effect of decentralization on national development in Indonesia by the difference between the growth trajectory of Indonesia and that of the synthetic Indonesia, and Figure 2 indicates that this effect is at best small (Model 3) and at worst either nonexistent or negative (Models 1,2 , and 4).

How confident are we in these findings? We turn to this question in Figure 3, which contains the results of our placebo analysis (we present results here for Models 1-3). The thick black line is the difference between growth trajectories in Indonesia and its synthetic counterpart (cal- 

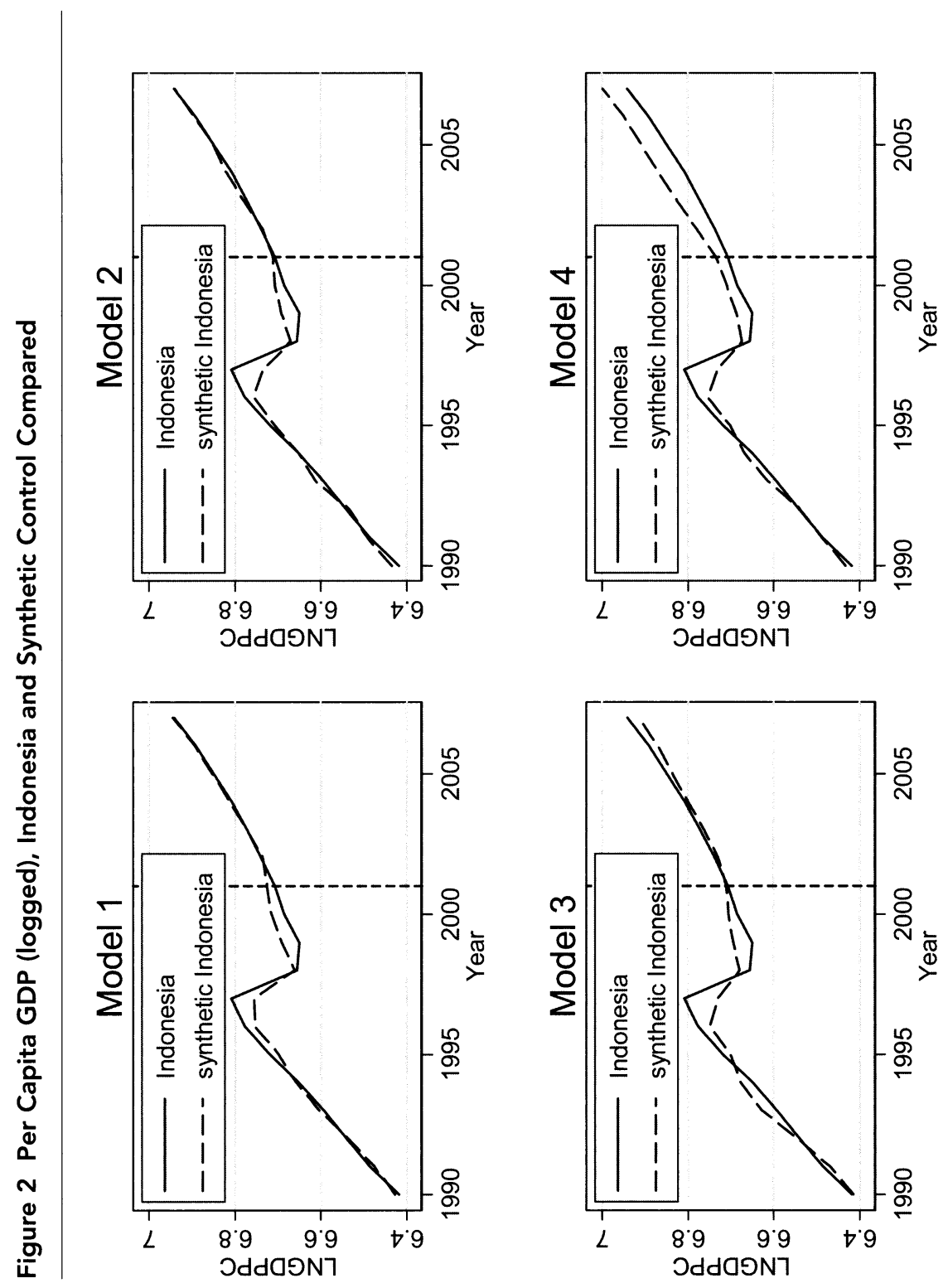


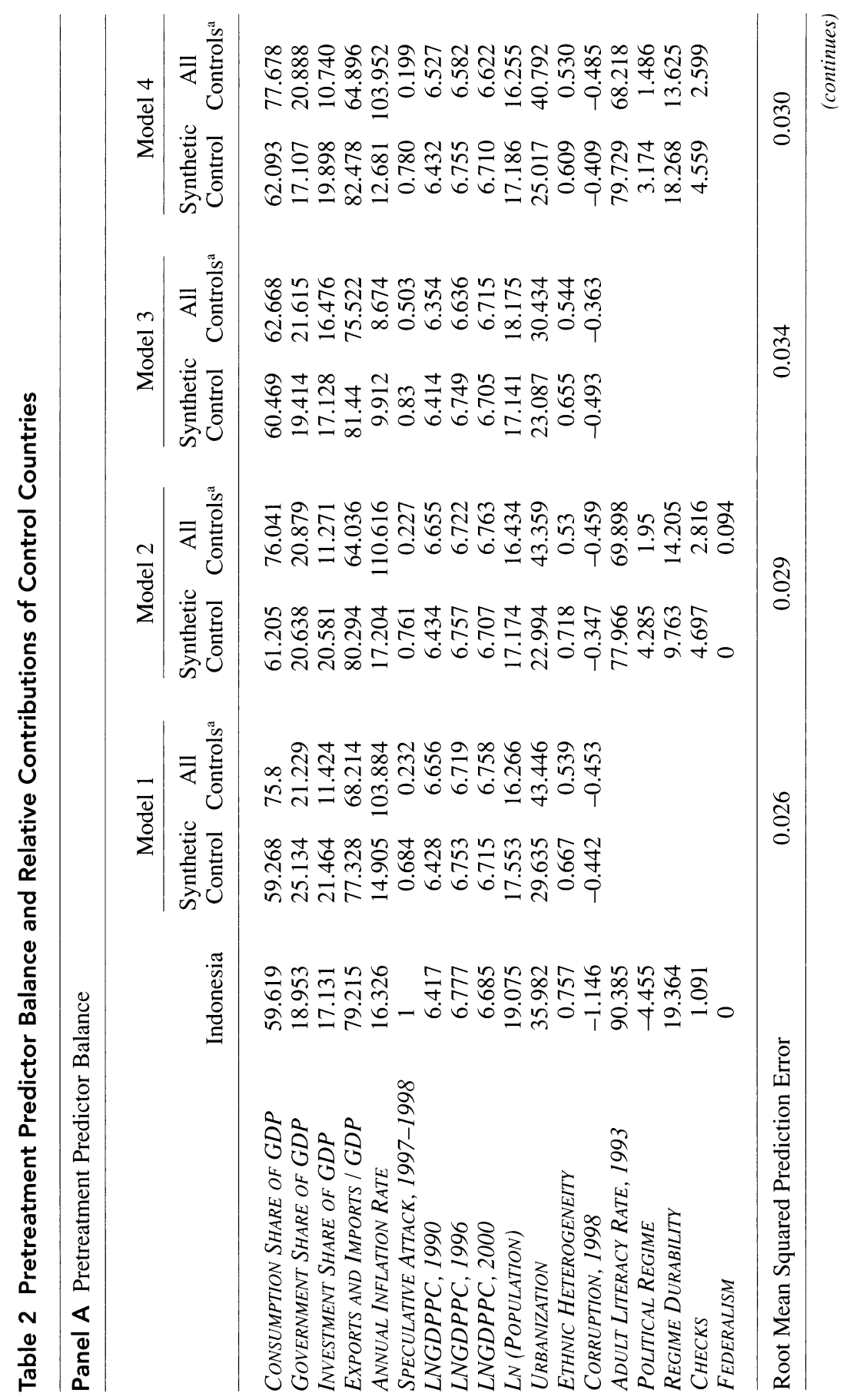




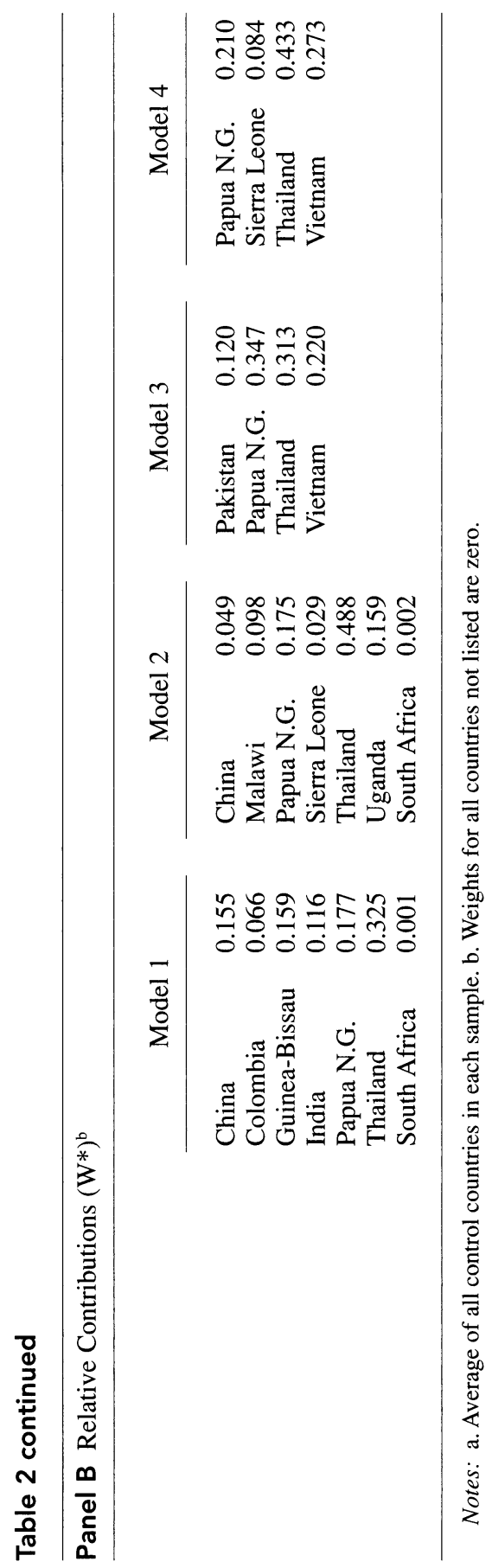


culated above), so that values below (above) zero indicate a lower (higher) than expected per capita GDP. Each thin gray line corresponds to a similar estimate derived for each individual country in the sample. If our estimates for Indonesia are large relative to those derived from other countries -in which case the black line would lie either above or below the mass of gray lines-then we conclude that decentralization significantly affected Indonesia's economic output. Otherwise, we will conclude that we have no evidence that decentralization significantly affected Indonesia's output.

As expected, Figure 3 shows that the estimates for Models 1 and 2, which found that decentralization had no effect on Indonesia's economic output, lie well within the range of placebo estimates. However, Model 3 (see Figure 2) indicated that if we discard all non-Asian countries from the sample used to construct a synthetic Indonesia, we estimate a small positive effect of decentralization on economic output. But Figure 3 gives us a sense of our confidence around that estimate-and it shows that this Model 3's estimated effect lies precisely in the middle of the ranges estimated in the placebo study using that sample of countries. We cannot conclude from these results that decentralization has had any effect on Indonesia's economic output. This conclusion holds even if we discard all placebo control cases from Model 3 whose RMSPE is more than twice that of Indonesia. ${ }^{5}$

Taken together, these results indicate that Indonesia's 2001 decentralization has not had any appreciable effect on Indonesia's economic performance. What effect decentralization has had, moreover, is indistinguishable from what we estimate using a placebo case study methodology. These results are disappointing for proponents of decentralization as a development strategy and call for further investigation. It is to this task that we now turn.

\section{Three Pathologies of Indonesian Decentralization}

We focus our discussion of the pathologies of Indonesian decentralization on two central political economy mechanisms linking decentralization to superior development outcomes. Because decentralization gives power to subnational governments, both require us to turn our attention to subnational political processes and the outcomes they produce. The first claim is that interjurisdictional competition forces all local governments to adopt better policies. The second claim is that local democracy forces local governments to adopt better policies. Indonesia's experiences over the past decade reveal that neither of these two mechanisms 
Figure 3 Placebo Study Results
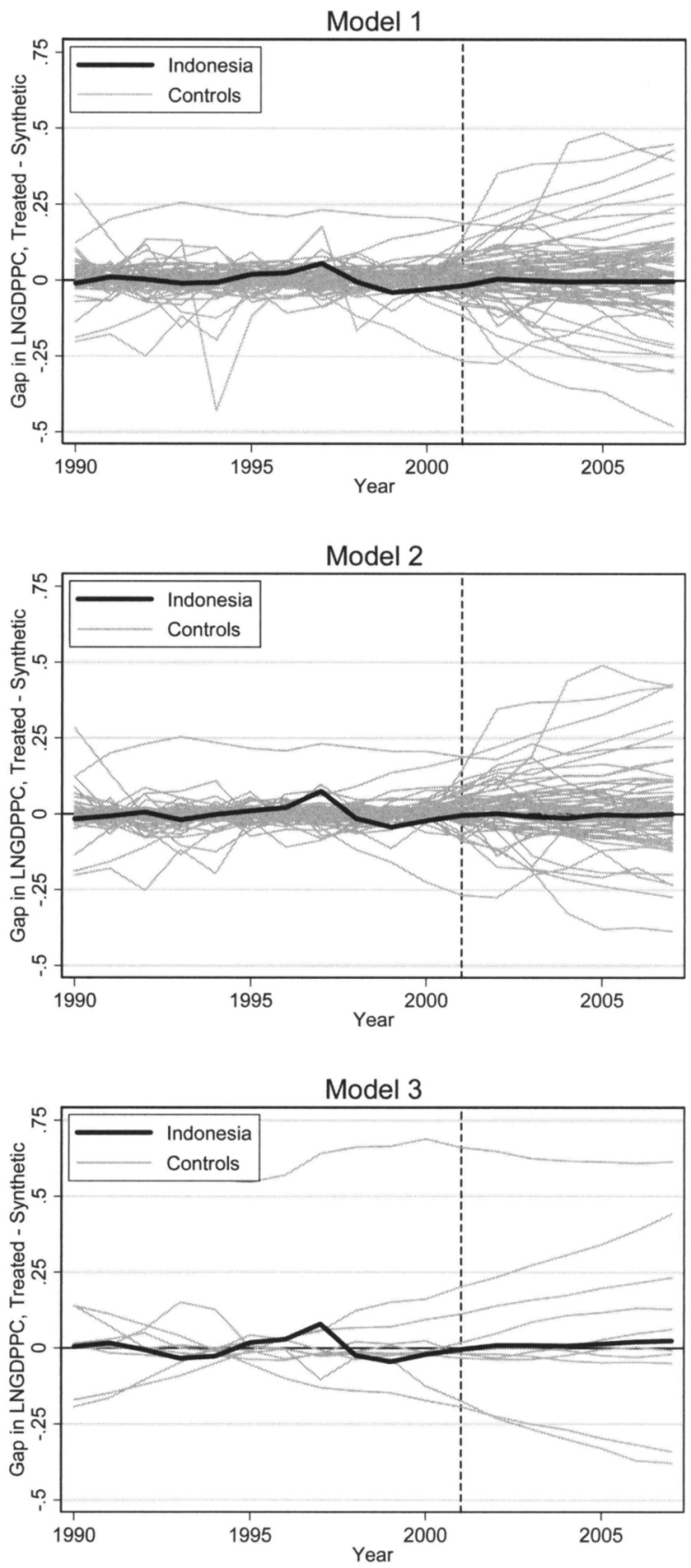
appears to be consistently at work across local governments. While local governments are now free in principle to compete over productive resources, in contemporary Indonesia extreme heterogeneity across districts and factor immobility hinder these competitive pressures. And although under decentralization local governments are now more accountable to their citizens than before, our field research demonstrates that socioeconomically backward districts-those for which decentralization's benefits are most critical-are least likely to have responsive local governments that are punished by their citizens for failing to adopt welfare-enhancing policies.

\section{Heterogeneous Districts}

The literature on decentralization suggests that interjurisdictional competition for resources (usually capital, but also labor) provides a marketlike incentive for governments to provide good policies (see, for example, Montinola, Qian, and Weingast 1995; Qian and Roland 1998; Weingast 1995). Under decentralization, local governments are free to experiment and innovate; those governments that respond to market demands to provide good policies will attract capital, and those that fail to adopt good policies will not. Seeing this, the latter group of governments will adopt policies that resemble the former. Citing this same literature, though, Hongbin Cai and Daniel Treisman (2005), note that these theoretical results depend critically on the assumption that jurisdictional units are sufficiently similar for competition to be feasible. As an illustrative example, they offer the following: "Even if the Russian republic of Buryatia were to install high-speed fibre-optic cables, it would not divert much business from Moscow and St. Petersburg" (Cai and Treisman 2005, 818). This is because Moscow and St. Petersburg are so different from their more backward counterparts that no amount of public goods investment or good government in the backward regions could induce most businesses to relocate there. Cai and Treisman (2005) further demonstrate that under such conditions, the governments of backward regions will actually be more likely to adopt predatory local regulations, a claim we find plausible but that we do not address in this study.

Are Indonesia's regions similar enough to one another that all regions can feasibly compete for the same productive resources? We argue that they are not. Geographical differences are most obvious. Throughout history, proximity to key trade routes has been an important driver of regional development outcomes, and today, for example, provinces located near Singapore enjoy significant locational advantages over other provinces in attracting investment in manufacturing. The city of Batam 
(Kota Batam) in the province of Riau Islands, located less than ten miles from Singapore, enjoys a series of business-friendly regulatory exemptions, including exemptions on all import, export, and value-added taxes, that make it an attractive hub for manufacturers. According to Batam Center (2009), "proximity to Singapore is one of the advantages so investors will not feel isolated in Batam. Batam is developed to take benefit of the progress that has been achieved by its neighbour." While other cities in Indonesia might also be designated as free trade and investment zones, none could replicate Batam's close proximity to Singapore, and hence none could enjoy the locational benefits that Batam enjoys. It is also worth noting that Batam's probusiness policies are the result not only of a cooperative local government that works closely with industry groups (Batam Center 2009), but they also required central government approval. Central government regulations, for example, still forbid all trade from the Batam free trade zone outside of five designated ports (Jakarta Post, January 20, 2009). While Kota Batam's growth prospects under decentralization are quite high, it is not realistic to believe that competitive pressures could force other cities and regencies to adopt similar policies in order to recreate Kota Batam's success.

Human capital endowments differ starkly as well, both across regions and within them. Across provinces, adult literacy rates in 2005 ranged from a high of 98.87 percent in North Sulawesi to a low of 71.58 percent in Papua (Statistics Indonesia 2009), and the latter figure is optimistic at best. Within the province of Central Java, local literacy rates range from a high of 96.53 percent in Kota Salatiga to a low of 74.89 percent in the kabupaten of Sragen. While it is certainly possible that governments in Salatiga and Sragen could each adopt investmentfriendly policies, it is unlikely that any sort of policy innovation in Sragen could entice firms in need of a skilled workforce to relocate from Salatiga. ${ }^{6}$ Development-enhancing policy reforms in Sragen may occur, but if so, they will not be driven by interjurisdictional competition.

The examples of interregional differences in geography and human capital are illustrative, but there may be other ways in which regions are similar, meaning that decentralized governance can still prompt competitive pressures in other domains. The case of Kota Batam, moreover, may be an extreme exception. One way to check if, on balance, decentralization has generated enough pressures to produce superior performance is to examine how development outputs have changed across regions under decentralization. Consistent with our focus on economic performance, we focus on gross regional domestic product (GRDP) as our development output of interest. If decentralization has led to policy convergence 
on prodevelopment policies, then due to the law of diminishing returns, growth rates in GRDP should be negatively correlated with initial GRDP at the regency level-the well-known convergence hypothesis derived from the neoclassical growth model (see Barro 1999, 8-12). If heterogeneity matters in the way that we expect, such that there are fundamental differences across regencies (either in endowments or in policies) that have effects on development, then there should be no relationship between initial GRDP and subsequent growth.

We adjudicate between these two possibilities using data on regencylevel GRDP since decentralization. We have data on non-oil and gas GRDP in constant 2000 prices from 2000 (prior to decentralization) to 2006 , and we investigate the convergence thesis by comparing per capita GRDP growth from 2000 to 2006 with initial per capita GRDP. Because we wish to calculate growth in per capita GRDP (which is only available in current prices), we merge the constant-price GRDP data with population data, which is available from 2003 to 2007. We must estimate regency-level population for 2000 , which we do by calculating each regency's population growth rate from 2003 to 2007 (assuming a geometric growth rate) and projecting this backward to obtain each district's estimated population in $2000 .{ }^{7}$ After obtaining per capita GRDP for 2000 and 2006, we estimate average yearly growth rates from 2000 to 2006, again assuming geometric growth. ${ }^{8}$

The results (see Figure 4) clearly show only a slight negative correlation between initial district-level GRDP and subsequent growth in GRDP and no correlation between initial district-level GDP and the simple change in GRDP. These correlations, moreover, are far from significant at conventional levels.

We conclude from this exploration of regional heterogeneity that in the time period for which directly comparable data are available, there is no evidence of convergence across regencies. This finding is consistent with our view that interjurisdictional heterogeneity hampers the ability of interjurisdictional competition to foster improved economic outcomes, and these results complement existing work that shows that across Indonesia, confiscatory local taxes and charges increased after 2001 (Lewis 2003). We are, of course, open to the possibility that there is a conditional negative correlation between initial GRDP and subsequent growth, one that emerges when we control for alternative determinants of growth such as geography, resources, or human capital endowments. Neil McCulloch and Bambang Sjahrir (2008) have in fact found evidence of conditional convergence across regencies. But this is evidence that heterogeneity across regions matters in the way that we expect that it does, further 
Figure 4 Convergence in Regional GRDP?

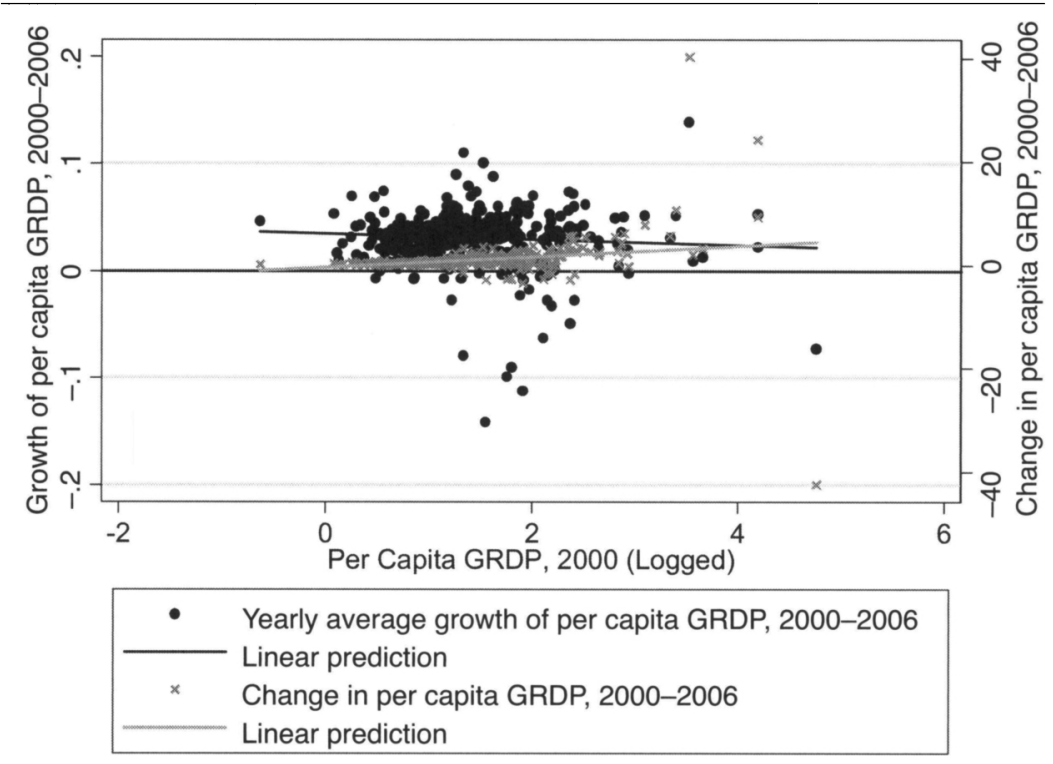

Note: GRDP is regency-level gross regional domestic product (excluding oil and gas).

challenging the claim that simple competition creates convergence on development-enhancing policies. It is important nevertheless to caution that our findings may change with longer-term data and that we are unable, using these methods, to distinguish the following two possibilities: (1) heterogeneity across districts means that interjurisdictional competition does not induce development-enhancing policies (our explanation), and (2) interjurisdictional competition does produce these policies but their effects are yet to be observed.

\section{Factor Immobility}

In the previous section, we questioned whether interjurisdictional competition is a logical outcome of decentralized governance if regions are heterogeneous. But even if all jurisdictions in Indonesia were sufficiently similar, so that even relatively poorly endowed jurisdictions could compete with the best endowed jurisdictions, a second key assumption that underlies the supposed benefits of interjurisdictional competition is that productive resources are mobile across jurisdictional boundaries. This mobility can be either responsive or anticipatory. An example of respon- 
sive mobility is when workers vote with their feet by moving from one jurisdiction with a bad, corrupt, or unresponsive local government to another jurisdiction with a better government. An example of anticipatory mobility is when a firm choosing where to site a production facility chooses from among many jurisdictions the one with the best regulatory environment. The assumption that factors are mobile across jurisdictional boundaries is central to the idea that jurisdictions can compete with one another - they can compete only if it is possible to draw productive resources (labor or capital) away from other jurisdictions.

But are Indonesia's factors of production actually mobile? We first consider labor. Rather than studying patterns of internal migration, we measure the potential mobility of labor in response to economic conditions directly, through individuals' professed willingness to move to obtain better work. A survey conducted in summer 2008 by the Indonesian Survey Institute (Mujani, Liddle, and Pepinsky 2008) contained several questions about local governance and corruption, and also a question on individual labor mobility. Respondents were asked, "If you had the ability to move to a different region to obtain better work, would you do so?" Table 3 (panel A) contains the distribution of responses. We see that most Indonesiansmore than 60 percent of those able to answer the question-would not move in response to the opportunity of better work. This simple result would suggest that it is unlikely that interjurisdictional labor mobility would be high enough to pressure most local governments to adopt better, more responsive policies.

It is theoretically possible that most Indonesians are unwilling to move because local governments have already adopted a variety of policies, and respondents have already sorted into those regencies whose policies most closely match theirs. One way to falsify this claim would be to show that economic factors do influence the likelihood that individuals would move due to economic opportunities. Panel B (columns 1-3) in Table 3 shows that as expected, when controlling for demographic characteristics as well as unobserved regency-specific characteristics, economic factors such as income, perceived change in household or employment status, and skill levels as proxied by education are all related to the probability that a respondent is willing to move in search of work.

We conclude from Table 3 that economic motives do drive individual propensities to migrate, which might seem to support the idea that jurisdictions can compete over labor (even though the proportion of labor that is biddable in this way is less than 40 percent). But the logic of interjurisdictional labor mobility is not simply that individuals will move in search of better employment opportunities. Rather, it is that they will do so in a way that disciplines unresponsive governments. The survey 


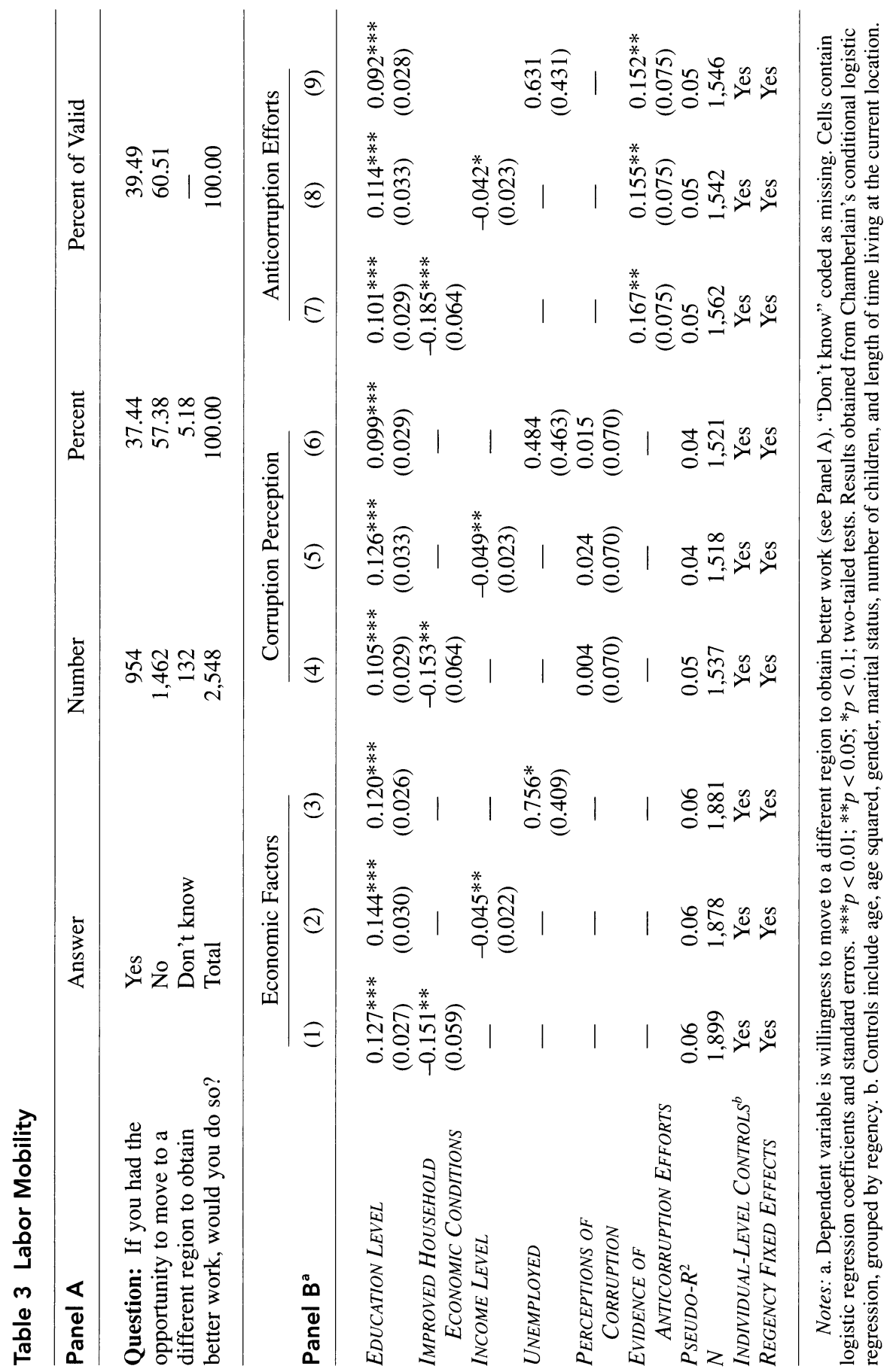


described previously asked respondents to rate both their perceptions of local government corruption and of local governments' efforts to eliminate corruption. Columns 4-6 in panel B test whether respondents who rate corruption as a major problem in their regional government are more willing to move. We find no evidence that this is the case. Columns 7-9 in panel B test whether perceived government effort influences respondents' willingness to move. If Indonesians are willing to vote with their feet, we should expect that favorable ratings of government anticorruption efforts should be negatively correlated with the propensity to move in search of work. What we find is the opposite: the better respondents rate local governments' anticorruption efforts, the more likely they are to express a willingness to move in search of work.

Together, these results call into question whether labor mobility is sufficient to force local governments to compete with one another to offer good policies. We estimate that fewer than 40 percent of Indonesians would actually move in search of better work. And although standard economic considerations do shape Indonesians' willingness to move, we find no evidence that what interjurisdictional labor mobility does exist conforms to the logic of competing for labor by offering good policies.

Now consider the mobility of other productive assets in Indonesia. Some assets such as investment capital are highly mobile across jurisdictions, but others-including mineral and agricultural resources-are quite simply immobile. A financial services firm facing an extortionary local government may simply move, at relatively small cost, to another jurisdiction with a less extortionary government. However, a mining company facing such an extortionary government has little recourse aside from either acceding to that government's demands or ceasing operations. The same is true for a poor peasant. Both of these options will have negative consequences for development. ${ }^{9}$ In all, the greater the contribution of such immobile assets to national development, the more unlikely the logic of interjurisdictional competition can discipline local governments.

In Table 4 we provide a lower bound on the percentage of Indonesia's national economic output that is "immobile," in the sense that it cannot plausibly move across borders in search of a better regulatory or political environment, for the most recent data available.

We determine an economic activity to be immobile if it is location specific, meaning that a necessary input to that activity is on (or under) the land (or sea). Essentially, this means agriculture, mining, and fuel and energy production; this is consistent with standard definitions of the related concept of "asset specificity" (see, for example, Boix 2003, 76-77). Obviously, these are rough calculations, and in coding all other 
Table 4 Asset Mobility by GDP Component

\begin{tabular}{|c|c|c|c|c|c|}
\hline Component of GDP & 2004 & 2005 & 2006 & 2007 & 2008 \\
\hline \multicolumn{6}{|l|}{ Immobile } \\
\hline $\begin{array}{l}\text { Agriculture, livestock, } \\
\text { fishing, and forestry }\end{array}$ & \multicolumn{5}{|c|}{ Agriculture, livestock, } \\
\hline Mining & $205,252.0$ & $309,014.1$ & $366,520.8$ & $441,006.6$ & $543,363.8$ \\
\hline Industry (petroleum) & $94,263.4$ & $138,440.9$ & $172,094.9$ & $182,324.3$ & $242,061.4$ \\
\hline $\begin{array}{l}\text { Electricity, gas, } \\
\text { and water }\end{array}$ & $23,730.3$ & $26,693.8$ & $30,354.8$ & $34,724.6$ & $40,846.7$ \\
\hline Total & $652,370.3$ & $838,318.1$ & $1,002,193.9$ & $1,199,648.1$ & $1,539,563.3$ \\
\hline \multicolumn{6}{|l|}{ Mobile } \\
\hline $\begin{array}{l}\text { Industry } \\
\text { (nonpetroleum) }\end{array}$ & $550,079.2$ & $621,920.4$ & $747,444.4$ & $886,329.6$ & $1,138,670.1$ \\
\hline Construction & $151,247.6$ & $195,110.6$ & $251,132.3$ & $305,215.6$ & $419,321.6$ \\
\hline $\begin{array}{l}\text { Commerce, hotel, } \\
\text { and restaurants }\end{array}$ & $368,555.9$ & $431,620.2$ & $501,542.4$ & $589,351.8$ & $692,118.8$ \\
\hline $\begin{array}{l}\text { Transportation and } \\
\text { communication }\end{array}$ & $142,292.0$ & $180,584.9$ & $231,523.5$ & $264,264.2$ & $312,454.1$ \\
\hline $\begin{array}{l}\text { Finance, real estate, } \\
\text { and corporate }\end{array}$ & $194,410.9$ & $230,522.7$ & $269,121.4$ & $305,213.5$ & $368,129.7$ \\
\hline Services & $115,740.9$ & $141,071.4$ & $168,459.2$ & $193,954.7$ & $226,223.6$ \\
\hline Total & $1,522,326.5$ & $1,800,830.2$ & $2,169,223.2$ & $2,544,329.4$ & $3,156,917.9$ \\
\hline Government services & $121,129.4$ & $135,132.8$ & $167,799.7$ & $205,343.9$ & $257,547.7$ \\
\hline Total GDP & $2,295,826.2$ & $2,774,281.1$ & $3,339,216.8$ & $3,949,321.4$ & $4,954,028.9$ \\
\hline $\begin{array}{l}\text { Total immobile, \% } \\
\text { of GDP }\end{array}$ & 28.4 & 30.2 & 30.0 & 30.4 & 31.1 \\
\hline $\begin{array}{l}\text { Total immobile, } \% \text { of } \\
\text { nongovernment GDP }\end{array}$ & 30.0 & 31.8 & 31.6 & 32.0 & 32.8 \\
\hline
\end{tabular}

Source: Badan Pusat Statistik (2009).

Note: Figures are in billions of rupiah, current prices.

economic activities as "mobile" we assume (impossibly) that it is costless to move any firm or factory. Even so, the lower bound of our estimate is the productive assets underlying more than 30 percent of Indonesia's private sector GDP are immobile. We see no evidence that this trend has declined over the short period of time under consideration. While the majority of Indonesia's GDP is still potentially mobile under this definition, the fact that such a substantial portion of Indonesia's economic output consists of assets that are immobile calls into question the ability of decentralization (or any other political innovation) to have forced local governments to compete over them. Other studies (e.g., 
Lewis 2003) have concluded that, in fact, many of the local taxes that have been levied since 2001 have been directed at such immobile assets as natural resources and cannot be explained by local fiscal needs.

\section{Endogenous Institutional Quality}

Our final mechanism that explains why Indonesian decentralization has not improved national development turns away from policy competition across jurisdictions to political competition within them. Building on insights from Avner Greif (2006) and Iwan Azis (2008), Azis and Maria Wihardja (2010) argue that the welfare effects of formal institutional innovations depend on socioeconomic conditions, inequality, participation, and other local factors that are present prior to these institutional innovations. Decentralization results in superior policy outcomes only when initial conditions have provided incentive structures, including local accountability, that reward welfare-enhancing public-private cooperation and punish welfare-corroding public-private cooperation. Hence, local capture, a condition under which local business elites capture or influence local economic and/or political institutions, can have a net effect on welfare that is either positive or negative, creating a reinforcing cycle between qualities of institutions and welfare that can be either virtuous or vicious.

More precisely, the likelihood that local governments will adopt welfare-enhancing policies depends on the ability of citizens to hold local governments accountable for the policies that they implement. High (low) levels of accountability generate high (low) social benefits, because citizens can (cannot) sanction leaders who fail to cooperate by voting them out of office. For example, where education, literacy, political awareness, and political participation are low, citizens will be less able to hold local governments accountable for the policies that they implement. In turn, these local governments will be less likely to implement policies that improve local welfare and instead will adopt distortionary policies that benefit themselves at the expense of the community at large. Because local leaders are now directly elected (as opposed to appointed), local business elites can also fund political campaigns in return for preferential regulations once these candidates are elected. The result is local capture of economic and/or political institutions by local business and political elites (see also Martinez-Vazquez and McNab 2003, 1607). As of February 2011, 30 percent of Indonesia's 524 local administration heads are under investigation as "graft suspects" (Jakarta Post, March 1, 2011). It is undeniable that local direct elections have been marred by money politics and political corruption due to the opportunities for business elites to fund local campaigns. 
In Indonesia, the result of these dynamics is the creation of raja kecil (little kings) who are unaccountable to their citizens (Hofman and Kaiser 2003 ) and, due to decentralization, no longer constrained in their confiscatory impulses by a strong central government either (Pepinsky 2008). Moreover, judicial and legal systems in Indonesia are very weak. Taken together, this causal sequence implies that in regencies with relatively poor socioeconomic conditions prior to decentralization, decentralization will be more likely to result in welfare-corroding policies. Where socioeconomic conditions are more propitious, decentralization has the precise opposite effect, resulting in welfare-enhancing policies. These dynamics are selfreinforcing. Local political institutions and policy outcomes co-evolve: governments with favorable initial conditions adopt good policies that further improve development and make subsequent good policies more likely, whereas those with unfavorable initial conditions adopt bad policies that further retard development and make subsequent bad policies more likely. In decentralized Indonesia, one of the main mechanisms through which this occurs is local capture through direct local elections.

It is difficult to develop common metrics for the quality of institutions and decisionmaking at the local level across all regencies. So to illustrate how conditions prior to decentralization have shaped local leaders' behavior after decentralization, and to chart the policy consequences of leaders' decisions, we present results from qualitative field research in five Indonesian regencies. These five case studies illustrate the political, social, and economic dynamics at the local level during the decentralization era. Note that this field survey does not attempt to provide quantitative evidence of endogenous institutional quality, but shows instead how the previously mentioned theory of endogenous institution may work by conducting a series of in-depth interviews of relevant political, economic, and social actors. The regencies were chosen to maximize variation in initial conditions, measured through indicators such as GDP per capita and institutional qualities such as local leadership, based on knowledge of these conditions - developed in consultation with the nonprofit local autonomy watchdog KPPOD (Komite Pemantauan dan Pelaksanaan Otonomi Daerah [Regional Autonomy Watch])—prior to the field study. Balikpapan was chosen because of high GDP per capita and good leadership; Prabumulih was chosen because of high GDP per capita but poor leadership; Sragen was chosen because of low GDP per capita but good leadership; Manggarai Barat was chosen because of low GDP per capita and poor leadership. Other indicators, such as the degree of local capture, are the targets of the field study, which can then illustrate the local political, social, and economic dynamics at work. 
A research team consisting of one of us along with a member of KPPOD visited each of the five districts in summer 2008. Questionnaires were prepared, and in each research site the team interviewed high-ranking public officials (including regents or mayors), political parties, opposition politicians, business associations, nongovernmental organizations (NGOs), local media, academics, and poor families. The goal of these interviews was to gauge the effectiveness and responsiveness of local leaders; the transparency of local regulations, budgeting processes, and public procurement; and the availability and efficacy of social programs. The team-in consultation with KPPOD—-then scaled the transcribed interviews across these domains to develop composite indicators of socioeconomic conditions, participation, local leadership, and local capture. The scaling system specified precise requirements that determined how each regency was scored along each indicator. For example, for the public-private partnership indicator, a district could receive a "high" score only if a partnership was identified that could be verified by the local business association. More detailed information about the data and methods for the field study are available from Azis and Wihardja (2008).

If the quality of local institutions prior to decentralization is endogenously shaped by socioeconomic conditions in the way that we expect, we should observe the following. First, in regencies with comparatively bad initial socioeconomic conditions, we should observe low levels of political participation by citizens. We measure this through participation in local development planning meetings (Musyawarah Rencana Pembangunan [Development Planning Consultations]), freedom of information, and freedom of expression. Where initial conditions are better, we should observe higher levels of political participation. Second, where political participation is low, creating low levels of accountability and low-quality leadership, we should observe "welfare-corroding" local capture. We measure leadership quality through the existence of corruption (and local elites' efforts to eliminate corruption); the quality of joint publicprivate partnerships to provide public goods like health care, infrastructure, and education; efforts to attract investment; and the public- versus privatemindedness of local leaders' cooperation with local elites. We measure local capture through the transparency of public procurement auctions, the transparency and efficacy of local regulations for encouraging private enterprise, and the provision of social welfare programs to needy or at-risk segments of the local population.

Our summary results appear in Table 5. As expected, we observe a close link between initial socioeconomic conditions and political participation, the quality of leadership, and local capture. 
Table 5 Initial Socioeconomic Conditions and Local Governance Indicators

\begin{tabular}{|c|c|c|c|c|c|}
\hline Kabupaten & Province & $\begin{array}{l}\text { ocioeconomic } \\
\text { Conditions }\end{array}$ & Participation & $\begin{array}{c}\text { Local } \\
\text { Leadership }\end{array}$ & $\begin{array}{c}\text { Local } \\
\text { Capture }\end{array}$ \\
\hline Balikpapan & East Kalimantan & Good & High & Good & No \\
\hline $\begin{array}{l}\text { Yogyakarta } \\
\text { City }\end{array}$ & Yogyakarta & Good & High & Good & No \\
\hline Prabumulih & South Sumatra & Medium & Low & $\mathrm{Bad}$ & Yes \\
\hline Sragen & Central Java & Medium & Low & Medium & Yes \\
\hline $\begin{array}{l}\text { Manggarai } \\
\text { Barat }\end{array}$ & $\begin{array}{l}\text { East Nusa } \\
\text { Tenggara }\end{array}$ & Bad & Low & Bad & Yes \\
\hline
\end{tabular}

Note: See text for methods and variable definitions.

Two brief anecdotes illustrate the causal sequence that produces these findings. In Manggarai Barat, whose initial socioeconomic conditions we rate as low, our study revealed that due to low levels of education, low participation, and leadership incompetence, a number of important government programs - which took the form of top-down political directives rather than bottom-up popular initiatives - were unsuccessful. For example, the Aldira project, in which a buyer committed to buy cassava seeds planted on the public land, failed because the seeds were planted during the wrong season. Incompetent local leaders and low local accountability, as well as poor infrastructure, deter investors from investing in Manggarai Barat, which has resulted in slow regional development and continued poverty in the years since decentralization. This, in turn, has decreased the likelihood that voters will elect competent local leaders in the future. This produces a vicious cycle between low popular welfare, poor institutional quality, and slow economic growth.

In Balikpapan, by contrast, the mayor has nurtured high levels of popular participation in governance by implementing a weekly Monday morning forum for all regency executives and a monthly meeting with local business leaders, including representatives from small businesses as well as large ones. Because of Balikpapan's relatively good socioeconomic conditions, its citizens participate in these political and economic arenas. Regular socialization events take place at the subdistrict levels, as local executives inform citizens about new local government regulations and other important information. It is not surprising that Balikpapan's local government - while certainly not free of all corruption or mismanagement-has performed well in adopting responsive legislation 
to promote local development goals. This is an example of a virtuous cycle in which high welfare co-evolves with high-quality institutions in the presence of propitious initial socioeconomic conditions. Such cooperative relationships between public officials and private stakeholders, generating proinvestment and prodevelopment outcomes, are consistent with what Christian von Luebke, Neil McCulloch, and Arianto Patunru (2009) term a "heterodox reform symbiosis" in related research on Solo, Central Java.

The most urgent question is how to break from the vicious cycle of Manggarai Barat and move toward the virtuous cycle of Balikpapan. Although this is beyond the scope of this article, some remarks (which we draw directly from the 2010 Human Development Report [UNDP 2010]) are worthy of note:

1. An amazing variety of institutions are compatible with human progress.... Indonesia ... made much of ... [its] progress in health and education under authoritarian rule. (UNDP 2010, 61)

2. Civil society organizations can also curb the excesses of markets and the state. In Indonesia nongovernmental organizations (NGOs), the press and trade unions pressured the state to expand political freedoms and deliver poverty reduction programmes after the 1997 financial crisis. (UNDP 2010, 63)

These remarks illustrate some key considerations for decentralized Indonesia. The first reminds us that institutional innovations are neither necessary nor sufficient to create developmentalist policymaking. The second indicates that a strong civil society - which should be the consequence of democratization, not decentralization-may be the key to making decentralization work.

Despite these suggestive results, a more definitive study would require repeated observation of these districts in order to study the co-evolution of welfare and institutions over time. Time series empirical indicators of institutional quality and local governance at the district level in Indonesia do not yet exist. ${ }^{10}$ In a cross-national context, many have studied how institutions affect economic growth, but studies of how socioeconomic conditions affect institutional quality are less common. Nadya Baryshnikova and Maria Wihardja (2011) do show that GDP per capita is positively associated with regulatory reform but unrelated to the rule of law, political stability, or voice and accountability (controlling for regime type, inequality, resource endowments, and population) across sixty-nine countries from 1996 to 2006. This result contradicts Daniel Kaufmann and Aart Kraay's (2002) finding that the national income negatively affects governance and 
suggests the existence of "vicious" and "virtuous" cycles cross-nationally. These findings notwithstanding, we conclude that more empirical studies on endogenous institutional change, both in Indonesia and cross-nationally, are necessary to help us understand how and when decentralization affects the quality of local institutions.

\section{Conclusion}

In this article, we have studied the effects of Indonesia's 2001 decentralization experiment on its subsequent economic development trajectory. Given that decentralization is seen by international development agencies and many political economists as a promising development tool, our estimates of its effects in Indonesia are disappointing. Using new methodological techniques that help us make explicit counterfactual statements of what we estimate Indonesia's development trajectory would have been without decentralization, we find no evidence that decentralization has had any effect on Indonesian development between its onset in 2001 and 2007, the most recent year for which full data are available.

In discussing our null finding, we have drawn attention to two key mechanisms - competition for productive resources across districts, and political competition within districts- that must obtain for decentralization to produce the positive economic outcomes held to be attributable to it. Using a combination of methods, we argue that there are strong reasons to suppose that these mechanisms do not function as expected in Indonesia. These findings are clearly related to Martinez-Vazquez and McNab's (2003) and Treisman's (2007) recent work on the theoretical case for decentralization and confirm the challenges that decentralization policies face in practice.

For policymakers, our findings suggest that politicians and development specialists should take care in designing large-scale policy interventions like decentralization. This is obvious in many respects, and we are heartened that, for example, the World Bank has been so careful to monitor Indonesian decentralization and so candid about its difficulties and challenges (see Hofman and Kaiser 2003 for a frank discussion). But our research into the pathologies of Indonesian decentralization suggests that in using economic performance considerations to justify decentralizing, policymakers should consider just what assumptions must be true for decentralization to yield superior economic outcomes. For decentralization to foster national development, a country must have relatively homogenous regions, highly mobile labor and capital, and strong accountability for local leaders. Indonesia's experience demonstrates how 
the absence of these three requirements can hamstring decentralization's effectiveness, particularly in the very districts where good governance is most needed.

In closing, we hasten to add that none of our findings imply that the opposite of decentralization - centralization-is a superior route to increased national economic performance. We find no positive effect of decentralization on Indonesian development, but no negative effect either. And we reiterate that there are many other reasons why we might find decentralized governance in Indonesia to be normatively good that have nothing to do with national economic performance. We accordingly hope that this study will complement others in evaluating the costs and benefits, both material and nonmaterial, of Indonesia's decentralization policy.

Thomas B. Pepinsky is assistant professor of government and associate director of the Cornell Modern Indonesia Project at Cornell University. He is the author of Economic Crises and the Breakdown of Authoritarian Regimes (2009) and of articles appearing in the American Journal of Political Science, Studies in Comparative International Development, World Politics, and other journals. His current research examines Islam, the economy, and voter preferences in democratic Indonesia.

Maria M. Wihardja is a research fellow at the Centre for Strategic and International Studies and a lecturer at the University of Indonesia. She has published in the Bulletin of Indonesian Economic Studies, Economics and Finance in Indonesia, and the Journal of Economic Development. She was a rapporteur for KOPEC-INCPECANU Asia G20 roundtables in November 2009 and October 2010. Her main research interests are institutions in developing countries and East Asian regionalism.

\section{Notes}

We thank Patrick Barron, Nancy Bermeo, Marcela Gonzalez-Rivas, Bill Liddle, Eddy Malesky, Neil McCulloch, Kevin Morrison, and seminar participants at Nuffield College, Oxford, the University of Freiburg, and Cornell for helpful comments on earlier drafts. We are responsible for all errors.

1. See Treisman (2007) for a review of these and other types of decentralization.

2. Some observers accordingly consider Indonesia to be fiscally decentralized since 2001, but it is important to recall that district governments are still primarily funded through DAU. The exception is resource rents, which accrue disproportionately to the regions that produce them. However, this was the case prior to 2001 as well.

3. The distance metric of choice in Abadie, Diamond, and Hainmueller $(2010,496)$ is $\left\|X_{1}-X_{0} W\right\|_{V}=\sqrt{\left(X_{1}-X_{0} W\right)^{\prime} V\left(X_{1}-X_{0} W\right)}$, where $V$ minimizes the mean squared prediction error of the synthetic control in the pretreatment period.

4. We have repeated our exercise dozens of times using different control variables and lags of $L N G D P P C$ in search of a specification that yields smaller 


\section{Appendix Population of Control Countries}

\begin{tabular}{|c|c|c|c|c|}
\hline \multicolumn{2}{|c|}{$\begin{array}{l}\text { Baseline Set of Predictors } \\
\text { (Model 1) }\end{array}$} & \multicolumn{2}{|c|}{$\begin{array}{l}\text { Expanded Set of Predictors } \\
\text { (Model 2) }\end{array}$} & \multirow{2}{*}{$\begin{array}{l}\begin{array}{l}\text { Asia Only } \\
\text { (Model 3) }\end{array} \\
\text { Bangladesh }\end{array}$} \\
\hline Algeria & Madagascar & Algeria & Malaysia & \\
\hline Argentina & Malawi & Argentina & Mali & China \\
\hline Bangladesh & Malaysia & Bangladesh & Mauritania & India \\
\hline Bolivia & Mali & Bolivia & Mauritius & Malaysia \\
\hline Botswana & Mauritania & Brazil & Mexico & Pakistan \\
\hline Brazil & Mauritius & Bulgaria & Morocco & Papua New \\
\hline Bulgaria & Mexico & Burkina Faso & Mozambique & Guinea \\
\hline Burkina Faso & Morocco & Burundi & Nicaragua & Philippines \\
\hline Burundi & Mozambique & Cameroon & Pakistan & Sri Lanka \\
\hline Cameroon & Nicaragua & Central & Panama & Thailand \\
\hline Central & Pakistan & African Rep. & Papua New & Vietnam \\
\hline African Rep. & Panama & Chad & Guinea & \\
\hline Chad & Papua New & Chile & Paraguay & \\
\hline Chile & Guinea & China & Peru & \\
\hline China & Paraguay & Colombia & Philippines & \\
\hline Colombia & Peru & Comoros & Poland & \\
\hline Comoros & Philippines & Costa Rica & Romania & \\
\hline Congo Republic & Poland & Democratic & Rwanda & \\
\hline Costa Rica & Romania & Republic & Senegal & \\
\hline Democratic & Rwanda & of Congo & Sierra Leone & \\
\hline Republic & Senegal & Ecuador & Sri Lanka & \\
\hline of Congo & Sierra Leone & Egypt & Sudan & \\
\hline Ecuador & Sri Lanka & El Salvador & Swaziland & \\
\hline Egypt & Sudan & Gabon & Tanzania & \\
\hline El Salvador & Swaziland & Ghana & Thailand & \\
\hline Fiji & Tanzania & Guatemala & Togo & \\
\hline Gabon & Thailand & Guinea & Tunisia & \\
\hline Gambia & Togo & Honduras & Turkey & \\
\hline Ghana & Tunisia & India & Uganda & \\
\hline Guatemala & Turkey & Ivory Coast & Uruguay & \\
\hline Guinea & Uganda & Jordan & Venezuela & \\
\hline Guinea-Bissau & Uruguay & Kenya & Vietnam & \\
\hline Honduras & Venezuela & Lesotho & Zambia & \\
\hline India & Vietnam & Madagascar & & \\
\hline Ivory Coast & Zambia & Malawi & & \\
\hline Jordan & & & & \\
\hline Kenya & & & & \\
\hline Lesotho & & & & \\
\hline
\end{tabular}


prediction errors from 1997 to 2000 . We are never able to eliminate these errors, and our substantive conclusions are never changed.

5. Doing so leads us to omit Bangladesh, China, Malaysia, Papua New Guinea, and Vietnam, leaving only five control cases.

6. We base this statement on our heterogeneity hypothesis. Sragen's growths of investment had been relatively high in past years, after the establishment of One-Stop-Service (see Azis and Wihardja 2008).

7. We wish to calculate population in 2000 ( pop $_{2000}$ ) using population in 2003 and population in 2007. Yearly population growth from 2003 to 2007, gpop $_{2003-2007}$, is $\left(\frac{\text { pop }_{2007}}{\text { pop }_{2003}}\right)^{\frac{1}{4}}-1$.

Assuming $g$ gop $_{2000-2002}=g$ gop $_{2003-2007}$, we estimate $p o p_{2000}=\frac{\text { pop }_{2003}}{\left(1+g p o p_{2003-2007}\right)^{3}}$.

8. Yearly per capita GRDP growth from 2000 to 2006, GGRDPPC $C_{2000-2006}$, is calculated as $\left(\frac{\text { GRDPPC }_{2006}}{\text { GRDPPC }_{2000}}\right)^{\frac{1}{6}}-1$.

9. The company or the peasant may respond by lobbying for the removal of distortionary policies, the outcome of which may (if successful) be welfareimproving but still represent a strictly second-best outcome over a distortionfree regulatory environment (Bhagwati 1982, 994-997).

10. KPPOD collected data on local governance for its Local Economic Governance Index in 243 Indonesian districts in 2008 , but this only provides a static snapshot of local governance during that period. If similar data are collected across these districts in the future, scholars will be able to study the co-evolution of institutions and welfare over time.

\section{References}

Abadie, Alberto, Alexis Diamond, and Jens Hainmueller. 2010. "Synthetic Control Methods for Comparative Case Studies: Estimating the Effect of California's Tobacco Control Program." Journal of the American Statistical Association 105, 490: 493-505.

Abadie, Alberto, and Javier Gardeazabal. 2003. "The Economic Costs of Conflict: A Case Study of the Basque Country." American Economic Review 93, 1: 112-132.

Azis, Iwan Jaya. 2008. "Institutional Constraints and Multiple Equilibria in Decentralization." Review of Urban and Regional Development Studies 20, 1: 22-33.

Azis, Iwan Jaya, and Maria M. Wihardja. 2008. "Field Survey in Five Districts in Indonesia on Local Capture and Social Welfare." Internal Report. Cornell University and KPPOD.

2010. "Theory of Endogenous Institutions and Evidence from an In-depth Field Study in Indonesia." Economics and Finance in Indonesia 58, 3: 309-334.

Badan Pusat Statistik. 2009. "Produk domestik bruto atas dasar harga berlaku menurut lapangan usaha (milyar rupiah)," http://bit.ly/a9GbHz (accessed December 7, 2010). 
Barro, Robert J. 1999. Determinants of Economic Growth: A Cross-country Empirical Study. Cambridge: MIT Press.

Baryshnikova, Nadya, and Maria M. Wihardja. 2011. "Cross-country Evidence of Endogenous Institutions." Working Paper. University of Adelaide and University of Indonesia.

Batam Center. 2009. "Investing in Batam," www.batam-center.web.id/ geninfo_investing.html (acessed December 7, 2010).

Beck, Thorsten, George Clarke, Alberto Groff, Philip Keefer, and Patrick Walsh. 2001. "New Tools in Comparative Political Economy: The Database of Political Institutions." World Bank Economic Review 15, 1: 165-176.

Bhagwati, Jagdish N. 1982. "Directly Unproductive, Profit-seeking (DUP) Activities." Journal of Political Economy 90, 5: 988-1002.

Boix, Carles N. 2003. Democracy and Redistribution. New York: Cambridge University Press.

Breuss, Fritz, and Markus Eller. 2004. "Fiscal Decentralization and Economic Growth: Is There Really a Link?” CESifo DICE Report 2, 1: 3-9.

Brodjonegoro, Bambang. 2009. "Fiscal Decentralization and Its Impact on Regional Economic Development and Fiscal Sustainability." In Decentralization and Regional Autonomy in Indonesia: Implementation and Challenges, ed. Coen J. G. Holtzappel and Martin Ramstedt, 196-221. Singapore: Institute for Southeast Asian Studies.

Cai, Hongbin, and Daniel Treisman. 2005. "Does Competition for Capital Discipline Governments? Decentralization, Globalization, and Public Policy." American Economic Review 95, 3: 817-830.

Cheema, G. Shabbir, and Dennis A. Rondinelli, eds. 1983. Decentralization and Development: Policy Implementation in Developing Countries. Beverly Hills: Sage.

Greif, Avner. 2006. Institutions and the Path to the Modern Economy. New York: Cambridge University Press.

Gurgur, Tugrul, and Anwar Shah. 2005. "Localization and Corruption: Panacea or Pandora's Box?” Policy Research Working Paper No. 3486. Washington, DC: World Bank.

Heston, Alan, Robert Summers, and Bettina Aten. 2006. "Penn World Table, Version 6.2." University of Pennsylvania, Center for International Comparisons of Production, Income and Prices, http://pwt.econ.upenn.edu/php_site/ pwt_index.php (accessed December 7, 2010).

Hofman, Bert, and Kai Kaiser. 2003. "The Making of the Big Bang and Its Aftermath: A Political Economy Perspective." Paper presented at the conference "Can Decentralization Help Rebuild Indonesia," Georgia State University, Atlanta.

Holland, Paul W. 1986. "Statistics and Causal Inference." Journal of the American Statistical Association 81, 396: 945-960.

Indonesia. 1999. Undang-undang Republik Indonesia nomor 22 tahun 1999 tentang "pemerintahan daerah."

Kaufmann, Daniel, and Aart Kraay. 2002. "Growth Without Governance.” Policy Research Paper No. 2928. Washington, DC: World Bank.

Kaufmann, Daniel, Aart Kraay, and Massimo Mastruzzi. 2008. "Governance Matters VII: Aggregate and Individual Governance Indicators for 1996-2007." Policy Research Working Paper No. 4654. Washington, DC: World Bank. 
Keefer, Philip, and David Stasavage. 2003. "The Limits of Delegation: Veto Players, Central Bank Independence and the Credibility of Monetary Policy." American Political Science Review 97, 3: 407-423.

Leblang, David. 2005. "Is Democracy Incompatible with International Economic Stability?" In The Future of the International Monetary System, ed. Marc Uzan, 168-198. Cheltenham, UK: Edward Alger.

Lewis, Blane D. 2003. "Tax and Charge Creation by Regional Governments Under Fiscal Decentralization: Estimates and Explanations." Bulletin of Indonesian Economic Studies 39, 2: 177-192.

Marshall, Monty G., Ted Robert Gurr, and Keith Jaggers. 2010. "Polity IV Project: Political Regime Characteristics and Transitions, 1800-2009." Center for Systemic Peace, www.systemicpeace.org/inscr/p4manualv2009.pdf (accessed December 7, 2010).

Martinez-Vazquez, Jorge, and Robert M. McNab. 2003. "Fiscal Decentralization and Economic Growth." World Development 31, 9: 1597-1616.

McCulloch, Neil, and Bambang Suharnoko Sjahrir. 2008. "Endowments, Location or Luck? Evaluating the Determinants of Sub-national Growth in Decentralized Indonesia." Policy Research Working Paper No. 4769. Washington, DC: World Bank.

Montinola, Gabriella, Yingyi Qian, and Barry R. Weingast. 1995. "Federalism, Chinese Style: The Political Basis for Economic Success in China." World Politics 48, 1: 50-81.

Mujani, Saiful, R. William Liddle, and Thomas B. Pepinsky. 2008. "Masalah sosial masyarakatan, Mei 2008.” Jakarta: Lembaga Survei Indonesia.

Oates, Wallace E. 1993. "Fiscal Decentralization and Economic Development." National Tax Journal 46, 2: 237-243.

Pepinsky, Thomas B. 2008. "Institutions, Economic Recovery, and Macroeconomic Vulnerability in Indonesia and Malaysia." In Crisis as Catalyst: Asia's Dynamic Political Economy, ed. Andrew MacIntyre, T. J. Pempel, and John Ravenhill, 231-250. Ithaca: Cornell University Press.

Persson, Torsten, and Guido Tabellini. 2003. The Economic Effects of Constitutions. Cambridge: MIT Press.

Qian, Yingyi, and Gérard Roland. 1998. "Federalism and the Soft Budget Constraint." American Economic Review 88, 5: 1143-1162.

Roeder, Philip G. 2001. "Ethnolinguistic Fractionalization (ELF) Indices, 1961 and 1985." University of California-San Diego, http://weber.ucsd.edu/ $\sim$ proeder/elf.htm (accessed December 7, 2010).

Seymour, Richard, and Sarah Turner. 2002. “Otonomi daerah: Indonesia's decentralization experiment." New Zealand Journal of Asian Studies 4, 2: 33-51.

Simandjuntak, Marsillam. 2003. "Indonesia: Risks Abound, a Case for Decentralization." Paper presented at the conference "Can Decentralization Help Rebuild Indonesia," Georgia State University, Atlanta.

Statistics Indonesia. 2009. "Tabel 3.1.1. Angka melek huruf penduduk umur 15 tahun ke atas menurut provinsi dan kab/kota," http://bit.ly/dNcNeY (accessed December 7, 2010).

Teorell, Jan, Nicholas Charron, Marcus Samanni, Sören Holmberg, and Bo Rothstein. 2009. "The Quality of Government Dataset, Version 17June09." University of 
Gothenburg, Quality of Government Institute, www.qog.pol.gu.se 9 (accessed December 7, 2010).

Tiebout, Charles M. 1956. “A Pure Theory of Local Expenditures.” Journal of Political Economy 64, 5: 416-424.

Treisman, Daniel. 2007. The Architecture of Government: Rethinking Political Decentralization. New York: Cambridge University Press.

UNDP (United Nations Development Programme). 2010. Human Development Report 2010. The Real Wealth of Nations: Pathways to Human Development. New York: Palgrave Macmillan.

von Luebke, Christian, Neil McCulloch, and Arianto A. Patunru. 2009. "Heterodox Reform Symbioses: The Political Economy of Investment Climate Reforms in Solo, Indonesia." Asian Economic Journal 23, 3: 269-296.

Weingast, Barry R. 1995. "The Economic Role of Political Institutions: Marketpreserving Federalism and Economic Development." Journal of Law, Economics, and Organization 11, 1: 1-31.

World Bank. 2009. World Development Indicators. Washington, DC: World Bank. Available at http://go.worldbank.org/U0FSM7AQ40. 


\section{ASIAN \\ SURVEY}

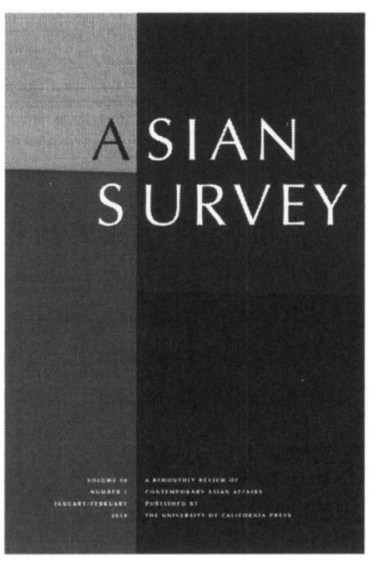

EDITOR//

Lowell Dittmer

DETAILS //

ISSN: 0004-4687

eISSN: $1533-838 X$

February, April, June, August,

October, December

Impact Factor: 0.341

Asian Survey provides penetrating analysis and commentary on the politics, economics, social issues, and foreign relations of countries from Afghanistan to the Pacific Rim. Since 1961, this scholarly yet accessible journal has offered empirically grounded insider perspectives on important current events, making it one of the most widely read and quoted sources on developments in the region.

WWW.UCPRESSJOURNALS.COM 